\title{
PERSONALITY AS AN OBJECT OF CIVIL LEGAL PROTECTION IN MEANS OF ARTICLE 16.1 OF THE CIVIL CODE OF THE RUSSIAN FEDERATION
}

\author{
Andrey N. Bocharov \\ Legal Consulting Company “Arbitr”, Rostov-on-Don, Russian Federation
}

Introduction: a person's personality is a complex phenomenon. Within the framework of legal regulation, this category receives a specific refraction, which differs significantly depending on the applicable branch of law. For civil law, it acts as an object of civil law relations. This work aims to critical understanding of the category of personality in the context of its use in the norm of Article 16.1. Civil Code. Methods: the methodological basis of this study is a set of methods of scientific knowledge, among which the main place is occupied by the methods of formal legal, systemic, hermeneutical and dialectical. Results: the author's position is based on the need to recognize for the person the nature of the intangible good. Consequently, an analysis of the identity of the citizen as a good is made, the results of which establish that the specificity of the individual consists in the impossibility of regulating it with the help of law, but in the need to protect it. This need is justified by the a priori social value of the individual as a boon for the law, as opposed to material goods, which possess, above all, a circulating value. Formed civil-legal definition of personality - a set of individualizing properties and characterological features of the individual, generalized by a single legal will and forming the civil-legal legal personality of an individual. The combination of personality traits as a civil and legal category indicates compensation for damage as the most optimal way to protect a given intangible good due to the impossibility of in-kind replenishment of any negative impacts on it. Conclusions: the identity of a citizen is one of the fundamental categories of civil law. The most rational way to protect it - compensation for damage.

Key words: person, civil law, damage compensation, legal relationship, good, method of protection, legal personality, citizen.

Citation. Bocharov A.N. Personality as an Object of Civil Legal Protection in Means of Article 16.1 of the Civil Code of the Russian Federation. Legal Concept, 2019, vol. 18, no. 2, pp. 107-111. (in Russian). DOI: https:// doi.org/10.15688/lc.jvolsu.2019.2.17

\section{ЛИЧНОСТЬ КАК ОБЬЕКТ ГРАЖДАНСКО-ПРАВОВОЙ ЗАЩИТЫ ПО СМЫСЛУ СТ. 16.1 ГРАЖДАНСКОГО КОДЕКСА РФ}

\author{
Андрей Николаевич Бочаров \\ Юридическая консалтинговая компания «Арбитр», г. Ростов-на-Дону, Российская Федерация
}

\footnotetext{
Введение: личность человека является комплексным феноменом. В рамках правового регулирования данная категория получает специфическое преломление, которое значительно отличается в зависимости от применимой отрасли права. Для гражданского права она выступает в качестве объекта гражданско-правоح вых отношений. Настоящей работой преследуется цель критического осмысления категории личности в 궁 контексте ее использования в норме ст. 16.1 ГК РФ. Методы: методологическую основу данного исследования составляет совокупность методов научного познания, среди которых основное место занимают формально-юридический, системный, герменевтический и диалектический методы. Результаты: авторская пооै зиция основывается на необходимости признания за личностью характера нематериального блага. Следова朩 тельно, производится анализ личности гражданина как блага, по результатам которого устанавливается, что специфика личности состоит в невозможности регулировать ее с помощью права, но в необходимости ее () защиты. Последняя обоснована априорной социальной ценностью личности как блага для права в противо-
} 
положность материальным благам, обладающим, прежде всего, оборотной ценностью. Формируется гражданско-правовое определение личности - совокупность индивидуализирующих свойств и характерологических черт индивида, генерализованных единой юридической волей и образующих гражданско-правовую правосубъектность физического лица. Совокупность признаков личности как гражданско-правовой категории указывает на компенсацию ущерба, как наиболее оптимальный способ защиты данного нематериального блага по причинам невозможности натурального восполнения любых негативных воздействий на него. Выводы: личность гражданина является одной из фундаментальных категорий гражданского права. Наиболее рациональный способ ее защиты - компенсация ущерба.

Ключевые слова: личность, гражданское право, компенсация ущерба, правоотношение, благо, способ защиты, правосубъектность, гражданин.

Цитирование. Бочаров А. Н. Личность как объект гражданско-правовой защиты по смыслу ст. 16.1 Гражданского кодекса РФ // Legal Concept = Правовая парадигма. - 2019. - Т. 18, № 2. - C. 107-111. - DOI: https://doi.org/10.15688/lc.jvolsu.2019.2.17

\section{Введение}

Одним из самых многогранных понятий в структуре парадигмального развития человеческой цивилизации является личность. Оно нашло свое отражение в обширном перечне социальных и гуманитарных наук, неоднократно трансформировалось в процессе жизнедеятельности общества. Возможно, наибольшую ценность категория личности приобретает в сфере правового регулирования. Существует достаточное количество работ, развивающих представления о личности с точки зрения конституционного, уголовного, уголовно-процессуального права, теории прав человека. Значимым же пробелом в данном направлении до сих пор обладает лишь цивилистическая научная мысль, несмотря на регулярно предпринимаемые различными авторами попытки выработать единый подход к трактовке личности в сфере гражданско-правового регулирования. Не претендуя на универсальность, представляется уместным попытаться дать исчерпывающее, ясное представление о личности в узком разрезе строго определенного правоотношения.

С 2013 г. в Гражданском кодексе РФ (далее - ГК РФ) действует ст. 16.1 «Компенсация ущерба, причиненного правомерными действиями государственных органов и органов местного самоуправления» [1]. Согласно данному положению «ущерб, причиненный личности или имуществу гражданина... подлежит компенсации». Таким образом, очевидно использование законодателем понятия личности для построения юридического механизма компенсации правомерно причиненного ущер- ба. Следовательно, целью данной работы логично обозначить критическое осмысление категории личности в контексте ее использования в норме ст.16.1 ГК РФ. Для реализации указанной цели наиболее оптимально уменьшить фокус научного внимания к рассматриваемой проблематике и в качестве конкретной задачи исследования установить теоретическое препарирование категории личности в качестве объекта гражданско-правовой защиты в том смысле, которым наделяет ее норма ст.16.1 ГК РФ. Методический инструментарий такого изучения составляют формально-юридический, системный, герменевтический и диалектический методы.

\section{Личность гражданина как благо}

Для успешной трансляции в правовую плоскость такого феномена человеческого бытия, как личность, необходимо отождествление его с некоторой обобщенной юридической категорией, входящей в базовое понятийное ядро отдельной отрасли. Для гражданского права в подобном качестве разумно использовать категорию объекта гражданского правоотношения. Тем не менее отсутствие единства во взглядах относительно содержания данного понятия в цивилистической науке вынуждает искать менее формальные, но более приближенные к существу исследуемых феноменов термины. В русле указанных размышлений следует согласиться с мнением В.В. Долинской, разделяющей точку зрения о сравнительной тождественности понятия «объект гражданского правоотношения» термину «благо» [3, с. 12-21]. Действитель- 
но, в контексте рассматриваемого предметного ряда данная лексика обладает значительно большей операциональной адекватностью за счет расширенной информативной составляющей.

Понимание блага в сфере нормативноправового регулирования согласно общей логике законодательного строительства должно сводиться либо к аксиологическим характеристикам явления, его защите, либо одновременно к двум указанным подходам. Общность объектов, преимущественно осмысляемых в русле первого из них, представлена в гражданском законодательстве более сложно и структурировано, так как предполагает регулятивную функцию права, реализуемую в отношении оборота блага, тогда как вторая - лишь его защиту. Существующие споры относительно дифференцированности охранительной функции и ее соотношения с защитой в текущем срезе научного интереса к рассматриваемым правоотношениям не имеют существенного значения, так как охранительная функция в любом из вариантов ее выделения будет тяготеть к одному из обозначенных полюсов. Более значимым следует признать качественное различие ценности блага в случае учета его аксиологических оборотных характеристик и при сингулярной защите блага. Ценность блага как таковая присутствует в обоих случаях, однако для первого варианта в правовой плоскости она предстает именно как оборотная ценность, тогда как для благ, подлежащих исключительно защите, следует говорить об априорной социальной ценности, не зависящей от рыночных условий.

В качестве иллюстрации к последней схеме нормативного преломления блага в гражданско-правовой сфере личность как юридическая категория подходит наилучшим образом. Представляя собой классическое нематериальное благо, личность является базовой категорией гражданско-правовой витальности субъекта, поскольку только наличие личности как совокупности индивидуализирующих свойств и характерологических черт индивида, генерализованных единой юридической волей, образует гражданско-правовую правосубъектность физического лица.
Правоотношения, возникающие относительно личности, не могут регламентировать внутреннюю структуру данного феномена, так как минимальные операционные модули правового отражения не в состоянии надлежаще рефлексировать признаки явления в юридическую плоскость социальной жизни, следовательно, правовая манипуляция с целью регламентации внутреннего содержания явления невозможна. Однако ввиду указанной роли в процессе субъектообразования, личность необходимо считать неопровержимой юридической ценностью, а значит подлежащей защите, воплощенной в нормах позитивного права.

\section{Специфика}

\section{гражданско-правового механизма} защиты личности

Отличительной чертой диспозитивного гражданско-правового регулирования является относительный (в сравнении с иными отраслями права) плюрализм способов защиты. Это порождает необходимость установления строгой алгоритмизации процесса избрания одного из них в зависимости от видовых и индивидуальных свойств объекта защиты. В случае с личностью необходимо констатировать значительное упрощение данной процедуры ввиду рассмотренных выше особенностей существования личности в юридической природе. Любое негативное воздействие на внутреннюю структуру личности приводит к ее необратимому изменению вплоть до частичной потери правосубъектности. В таких условиях классические для гражданского права способы защиты в форме возмещения убытков и восстановления положения, существовавшего до нарушения права (и иные), которые ориентированы преимущественно на натуральное исполнение возникшего обязательства из умаления субъективного гражданского права, становятся неприменимыми в силу банальной невозможности возвращения состояния объекта, прерванного посягательством. Зарождающаяся в результате данного противоречия социальная несправедливость в своем корне несет строго юридический характер, так как при отсутствии адекватного ответа в форме юридической 
защиты свидетельствует о неспособности права выполнять делегированные ему функции. Единственным выходом, основанным на методологическом аппарате права, в данном случае следует считать применение принципа, который В.В. Груздевым был описан как гражданско-правовая эквивалентность [2, с. 63-75].

Однако любой принцип всегда остается лишь вектором движения, определяющим направление, но не конкретные формы реализации. Объективная же потребность в защите одного из наиболее ценных благ в парадигме человеческого существования требует и соответствующей ей объективации методов защиты. Компенсация ущерба в таком случае представляется наиболее оптимальной по целому ряду причин.

Во-первых, компенсация всегда ретроспективна, она воздействует на правоотношение необратимо измененное, что с учетом специфики личности как объекта защиты представляется единственным решением, не несущим в себе элементов «юридической схоластики». Во-вторых, компенсация в той форме, которая закреплена в ст. 16.1 ГК РФ, является классическим частноправовым институциональным феноменом, тогда как такие способы защиты, как признание права, в подобной ситуации неизбежно приобретают публично-правовой характер (что также имело место в историческом генезе правовых взаимоотношений личности и государства, о чем подробнее можно узнать в работе О.В. Михайленко [4]. В-третьих, требование гражданско-правовой эквивалентности при использовании компенсации ущерба легко исполняется за счет денежной эквивалентизации. Использование денег как наиболее универсального социального блага позволяет объективно оценить субъективную значимость защищаемого явления правовой действительности, а также избежать методологического тупика возмещения убытков и гражданско-правовой ответственности, суть которого состоит в примате натурального исполнения, а значит абсолютной тождественности размера и характера возмещения разнице состояния блага до и после умаления (подчас трудно дифференцируемой), которой правоприменитель практически никогда не добивается.
Необходимо сделать ремарку и упомянуть, что как таковое признание права в случае с компенсацией ущерба личности гражданина, причиненного правомерными действиями государственных органов и органов местного самоуправления также имеет место. Но выражено оно фактически в общем конституционно-правовом статусе личности и его признании на уровне правопорядка, что находит воплощение именно в правомерности деятельности публичноправовых образований, самой юридической квалификации правоотношения по норме ст. 16.1 ГК РФ, которая невозможна без признания за гражданином права на «юридическую личность».

\section{Вывод}

Личность как объект гражданско-правовой защиты представляет собой одну из базовых категорий гражданского права, так как непосредственно связана с формированием гражданской правосубъектности физического лица, ввиду чего обладает исключительной юридической ценностью, что не позволяет формировать механизм ее защиты по остаточному принципу. В силу необратимости изменений объекта при правомерном посягательстве на личность со стороны публичноправовых образований возникает исключительная применимость компенсации ущерба как способа восстановления нарушенного баланса прав.

\section{СПИСОК ЛИТЕРАТУРЫ}

1. Гражданский кодекс Российской Федерации (часть первая) от 30.11.1994 № 51-Ф3 (ред. от 03.08.2018) (с изм. и доп., вступившими в силу с 01.01.2019) // Российская газета. - № 238-239. 08.12.1994.

2. Груздев, В. В. Гражданско-правовая эквивалентность: понятие и сущность / В. В. Груздев // Журнал российского права. - 2018. - № 11. - С. 63-75.

3. Долинская, В. В. Объекты в гражданском праве и смежные понятия / В. В. Долинская // Вестник Юридического факультета ЮФУ. - Т. 5, № 1. 2018. - C.12-21.

4. Михайленко, О. В. Имущественная ответственность за вред, причиненный осуществлением публичной власти: теоретические аспекты и про- 
А.Н. Бочаров. Личность как объект гражданско-правовой защиты по смыслу ст. 16.1 ГК РФ

блемы ее реализации на практике / О. В. Михайленко. - М. : Волтерс Клувер, 2007. - 352 с.

\section{REFERENCES}

1. Civil Code of the Russian Federation (Part One) from 30.11.1994 № 51-FZ (as Amended on 03.08.2018) (with changes in force since 01.01.2019). The Russian Newspaper, 1994, December 8(no. 238-239). (in Russian).
2. Gruzdev V.V. Civil-Legal Equivalence: Concept and Essence. Journal of Russian Law, 2018, no. 11, pp. 63-75. (in Russian).

3. Dolinskaya V.V. Objects in Civil Law and Related Concepts. Bulletin of the Law Faculty of SFU, 2018, Vol. 5, no. 1, pp. 12-21. (in Russian).

4. Mikhailenko O.V. Property Liability for Damage Caused by the Exercise of Public Power: Theoretical Aspects and Problems of its Implementation in Practice. Moscow, Walters Kluver, 2007. 352 p. (in Russian).

\section{Information about the Author}

Andrey N. Bocharov, Legal Adviser, Legal Consulting Company “Arbitr”, 1-y Konnoy Armii St., 23/10, Office 21, 344029 Rostov-on-Don, Russian Federation, an.bocharov@yandex.ru, anb@arbitr.ooo, https://orcid.org/0000-0002-8210-959X

\section{Информация об авторе}

Андрей Николаевич Бочаров, юрисконсульт, Юридическая консалтинговая компания «Арбитр», ул. 1-й Конной Армии, 23/10, офис 21, 344029 г. Ростов-на-Дону, Российская Федерация, an.bocharov@yandex.ru, anb@arbitr.ooo, https://orcid.org/0000-0002-8210-959X 